\title{
Seasonal Progress of Charcoal Rot and Its Impact on Soybean Productivity
}

\author{
Alemu Mengistu, USDA-ARS-CGRU, 605 Airways Blvd., Jackson, TN 38301; and J. R. Smith, J. D. Ray, and N. Bellaloui, USDA- \\ ARS-CGRU, P.O. Box 345, Stoneville, MS 38776
} \begin{abstract}
95:1159-1166.
The seasonal progress of charcoal rot (caused by Macrophomina phaseolina) was measured over two growing seasons in four separate experiments: irrigated infested, irrigated non-infested, non-irrigated infested, and non-irrigated noninfested. Disease was assessed at V5, R1, R3, R5, R6, and R7 growth stages based on colony forming units (CFU) of M. phaseolina recovered from the lower stem and root tissues and the area under the disease progress curve (AUDPC). The population density of M. phaseolina increased slowly from the V5 to R6 growth stages and then rapidly from the R6 to R7 growth stages for all genotypes in all four experiments. Yield loss due to charcoal rot ranged from 6 to $33 \%$ in irrigated environments. The extent of yield
\end{abstract}

Abstract

Mengistu, A., Smith, J. R., Ray, J. D., and Bellaloui, N. 2011. Seasonal progress of charcoal rot and its impact on soybean productivity. Plant Dis.

loss was affected by severity of charcoal rot, which in turn was affected by year. Yield loss due to charcoal rot was consistently measured in all paired comparisons in irrigated environments, suggesting that charcoal rot can be an important disease in irrigated environments. Disease severity based on CFU accounted for more yield loss variation (42\%) than did the AUDPC (36\%) when used to assess disease. Growth stage R7 was found to be the optimum stage for assessing disease using CFU. In addition, screening soybean genotypes under irrigation environment may have utility in breeding programs where there is a need for evaluating soybean genotypes for both disease resistance and yield.
Charcoal rot of soybean (Glycine max (L.) Merr.), caused by Macrophomina phaseolina (Tassi) Goid., is a disease of economic significance (27). It has been reported to cause losses in the north central $(1,6,37)$ and southern United States as well as in tropical and subtropical regions of the world (27). When severe, charcoal rot reduces yield and seed quality $(27,36)$. This pathogen may infect at least 500 plant species, including economic hosts such as corn, sorghum, cotton, and tobacco $(28,36)$. Aboveground symptoms of charcoal rot on soybean appear after flowering, particularly at growth stages R5, R6, and R7 (7). Diseased plants may wilt and prematurely die, with dead leaves remaining attached to petioles and petioles remaining attached to stems $(15,28)$.

Optimum growth of $M$. phaseolina occurs in soil at high soil temperatures $(20,27)$. Colonization of host tissue is favored by high temperature and low soil moisture (5), and subsequent damage to plants and yield loss are greater under these conditions $(8,27)$. Low soil moisture is reported to increase growth (17) and enhance survival (26) of the pathogen. Drought conditions favor the development of charcoal rot in sorghum and sunflower, and yield suppression has been attributed to the influence of the combination of drought and charcoal rot $(8,11)$.

Much work has been done to elucidate the variability in morphology, physiology, pathogenicity, and genotype of $M$. phaseolina. However, the effect of charcoal rot and its impact on yield in soybean has not been adequately studied since it is apparently complicated by the compounding effect of varying drought stress levels from year to year (2). The methods used to estimate effects of charcoal rot on yield are confounded with the effects of drought

Corresponding author: Alemu Mengistu,

E-mail: alemu.mengistu@ars.usda.gov

Mention of trade names or commercial products in this publication is solely for the purpose of providing specific information, and does not imply a recommendation or endorsement by the U.S. Department of Agriculture.

Accepted for publication 18 May 2011.

doi:10.1094/PDIS-02-11-0100

This article is in the public domain and not copyrightable. It may be freely reprinted with customary crediting of the source. The American Phytopathological Society, 2011.
(2), and that has made it difficult to objectively separate and determine how much charcoal rot contributes to yield loss under such conditions. In order to objectively determine the effect of charcoal rot on soybean yield, irrigation treatment has to be utilized to remove the confounding effect of drought.

Kendig et al. (10) found that colonization of soybean roots by $M$. phaseolina at the R8 stage of growth was significantly greater in non-irrigated plots when compared to irrigated plots. However, no yield data were reported in this study. Mengistu et al. (14) also measured colonization of soybean roots and stems in determining propagule densities under different cover crop and tillage systems, but again no yield data were presented.

The availability of resistant or moderately resistant genotypes has been utilized in many crops, including soybeans, as a means to assess the impact of disease on yield under various sets of environments $(3,4,13,20,23)$. The use of soybean genotypes with similar maturity and yield but differing resistance could provide a better estimate of genotype performance. The objective of this research was to determine the population dynamics at various growth stages and measure yield responses of susceptible and moderately resistant soybean genotypes to $M$. phaseolina in four separate field experiments: experiment 1 was artificially infested and irrigated, experiment 2 was non-infested and irrigated, experiment 3 was artificially infested and non-irrigated, and experiment 4 was noninfested and non-irrigated.

\section{Materials and Methods}

Field plot design and treatments. Field trials with soybean were conducted in 2004 and 2005 at the Delta Research and Extension Center, Stoneville, MS ( $33^{\circ} 26^{\prime} \mathrm{N}$ lat.). The soil was a Bosket, fine-loamy, mixed, active, thermic Mollic Hapludalfs. Before planting each year, the field was tilled with either a disk-harrow or a spring-tooth field cultivator. The field was then divided into six grids, and 10 soil cores were collected per grid in a zigzag pattern to determine the colony forming units per gram of tissue $(\mathrm{CFU} / \mathrm{g})$ (15). The CFU/g of soil of M. phaseolina ranged from 5,500 to 6,200 in 2004 and from 6,800 to 8,000 in 2005. The site was then treated each year with methyl bromide (Hendrix and Dail Inc.) to reduce the number of microsclerotia (21). The methyl bromide (MB) and chloropicrin (CP) combination was injected into the soil as gas at a rate of $448.9 \mathrm{~kg} / \mathrm{ha}(29)$. The fumigant was injected through shanks spaced 9 inches apart to a depth of $30.5 \mathrm{~cm}$. 
Immediately following injection, a $1.5-\mathrm{ml}$ polyethylene film was placed over the treated area to reduce the dissipation rate of gases into the air and increase the retention of the fumigants in the soil. After 7 days, the polyethylene film was perforated to allow venting. Two days later, the polyethylene film was removed and 10 soil cores were taken at a depth of $30.5 \mathrm{~cm}$ from the original six grids to determine the level of CFU after MB-CP treatment. The CFU/g from the 10 cores following treatment showed a reduced level of inoculum, ranging from 475 to 650 in 2004 and 723 to 875 in 2005.

The fumigated area was divided into four sections: experiment 1 to experiment 4 . The treatments that received inoculum are referred to as artificially infested, and the treatments that did not receive inoculum are referred to as noninfested since lower CFU levels were detected. The noninfested treatment does not imply the absence of inoculum, since a lower level of CFU was detected. Experiment 1 was artificially infested and irrigated, experiment 2 was non-infested and irrigated, experiment 3 was artificially infested with no irrigation, and experiment 4 was non-infested with no irrigation. Four genotypes in two maturity groups were planted in each experiment in a randomized complete block design with three replications. The MG IV genotypes were DT97-4290 (19,21), moderately resistant to $M$. phaseolina, and Egyptian, susceptible to M. phaseolina (18). The MG III genotypes were AG 3905, moderate resistant to $M$. phaseolina, and DK 3964, susceptible to $M$. phaseolina. The MG III and IV resistant and susceptible genotypes were chosen because previous research has shown that yields between the two MG III and the two MG IV genotypes were similar under low level of inoculum (A. Mengistu, unpublished data).

Each plot was five rows wide $(0.61 \mathrm{~m}$ spacing) and $6 \mathrm{~m}$ long. Seeding rate was 26.4 seeds $\mathrm{m}^{-1}$ of row at a $2.5-\mathrm{cm}$ depth using a planter retrofitted with seed cone attachments and a hydraulic depth-control system. At planting, millet infested with $M$. phaseolina was applied in furrow at $1 \mathrm{~g}$ per $30.5 \mathrm{~cm}$ of row. Inoculum of M. phaseolina was produced according to Mengistu et al. (15), and noninfested plots received noncolonized millet. Production inputs were identical for all treatments and irrigation environments. Two irrigation environments were established during the season: nonirrigated, and a season-long irrigation that began at 21 days after planting and continued until maturity (Table 1). Irrigation was applied to designated plots by the furrow method using gated pipe according to Heatherly (9) when soil water potential at the $30-\mathrm{cm}$ depth decreased to approximately $-50 \mathrm{kPa}$. Plots were maintained weed free with pre-emergent and postemergent applications of labeled herbicides. The same area of land was used each year, and treatments were rerandomized each year. The planting dates, maturity group, growth stages, and harvest dates for the 2 years are listed in Table 1.

Seed yields were determined from a 6-m length of the three center rows of each subplot at plant maturity. Since the two maturity groups (MGs III and V) matured at different times, the plants from early MGs were hand cut and manually fed into a Massey Ferguson plot combine (MF 8XP, AGCO Corporation). The late MG genotypes were harvested using the plot combine. Harvested seeds were weighed to determine yield, and then the weight was adjusted to $12 \%$ moisture content.

Environmental data. Data on air temperature, precipitation, and soil temperature were obtained from the Stoneville weather station website (http://msa/ars.usda.gov/statmsa/weather.htm, Delta Research and Extension Center, 2007). Hourly measurements of water potential during the growing season were taken with a Watermark soil moisture sensor and a gypsum moisture block using a Watchdog Weather Station (Spectrum Technologies, Inc.) placed in each experimental test. The soil moisture sensors were placed within rows at $30 \mathrm{~cm}$ depth in a representative area of each experiment. Soil temperature data taken at 5.1- and 10-cm depth were obtained from the Stoneville weather station website and recorded at the non-irrigated site.

Sampling and disease assessment. Ten plants per plot were arbitrarily selected from each of four genotypes at growth stages V5, R3, R5, R6, and R7. Plants were selected from the outside rows of each plot, and samples included both the roots and aboveground portions of the plant. Disease assessment was made using CFU on samples taken from the lower stem and root, including lateral and fibrous roots, by excising the stem and roots below the cotyledonary node. Each sample was thoroughly washed and rinsed in water to remove excess soil, air dried, and then stored at $25^{\circ} \mathrm{C}$. The stem and root samples from each plot were bulked and ground in a Wiley Mill (Model 4) fitted with a 1-mm mesh screen. The mill was thoroughly cleaned between samples. The samples were then stored in sealed plastic containers at $4{ }^{\circ} \mathrm{C}$ until use. For each sample, $5 \mathrm{mg}$ of ground tissue was mixed in a Waring blender with $100 \mathrm{ml}$ of $0.525 \% \mathrm{NaOCl}$ for $3 \mathrm{~min}$, the triturate was collected over a $45-\mu \mathrm{m}$ pore size sieve and then rinsed out with $5 \mathrm{ml}$ of sterile distilled water into $100 \mathrm{ml}$ of melted potato dextrose agar (PDA, Difco Laboratories) that was maintained at $60^{\circ} \mathrm{C}$. The PDA was amended with rifampicin $\left(100 \mathrm{mg} \operatorname{liter}^{-1}\right)$ and tergitol $(0.1 \mathrm{ml})(20,27)$. The $100 \mathrm{ml}$ of PDA was dispensed equally into five plates. After 3 days of incubation at $30^{\circ} \mathrm{C}$ in the dark, the total counts of $\mathrm{CFU}$ from the five plates representing samples were taken from each plot, converted to CFU per gram (CFU count $\times 200$ ) of ground root and stem tissue, and expressed for each genotype. The area under the disease progress curve (AUDPC) was then calculated using the average CFU counts between each pair of adjacent sampling (12). The AUDPC was standardized by dividing it by the total length of the disease assessment period in order to make direct comparisons among epidemics within each experiment.

Data analysis. Data on CFU, AUDPC, and yield were analyzed using analysis of variance (ANOVA) performed using SAS's general linear mixed model procedure PROC REG, PROC MIX, and PROC GLM (SAS Institute), and the mean comparisons were made using Fisher's least significant difference test. Since irrigation and the four experiments were not replicated, data from each experiment in both years of this study were analyzed separately. Regression analysis was performed to estimate the relationship between CFU, AUDPC, and the difference in yield between resistant and susceptible genotypes.

Table 1. Date of planting, genotypes, maturity group, and the growth stages during which samples were taken for Macrophomina phaseolina quantification, and days until harvest for the four genotypes, under irrigated and non-irrigated environments in 2004 and 2005 at Stoneville, MS

\begin{tabular}{|c|c|c|c|c|c|c|c|c|c|c|}
\hline \multirow[b]{2}{*}{ Year } & \multirow{2}{*}{$\begin{array}{l}\text { Date of } \\
\text { planting }\end{array}$} & \multirow[b]{2}{*}{ Genotype } & \multirow[b]{2}{*}{$\mathbf{M G}^{\mathbf{z}}$} & \multicolumn{5}{|c|}{ Growth stages and corresponding days after planting } & \multicolumn{2}{|c|}{ Days until harvest } \\
\hline & & & & V5 & $\mathbf{R 3}$ & $\mathbf{R 5}$ & R6 & R7 & Non-irrigated & Irrigated \\
\hline 2004 & 4 May & $\begin{array}{l}\text { DT 97-4290 } \\
\text { EGYPTIAN } \\
\text { AG } 3905 \\
\text { DK } 3964\end{array}$ & $\begin{array}{l}\text { IV } \\
\text { IV } \\
\text { III } \\
\text { III }\end{array}$ & $\begin{array}{l}52 \\
54 \\
29 \\
29\end{array}$ & $\begin{array}{l}75 \\
77 \\
47 \\
47\end{array}$ & $\begin{array}{l}91 \\
93 \\
63 \\
63\end{array}$ & $\begin{array}{r}113 \\
115 \\
85 \\
85\end{array}$ & $\begin{array}{r}135 \\
137 \\
97 \\
97\end{array}$ & $\begin{array}{l}145 \\
145 \\
111 \\
111\end{array}$ & $\begin{array}{l}152 \\
152 \\
118 \\
118\end{array}$ \\
\hline 2005 & 6 May & $\begin{array}{l}\text { DT 97-4290 } \\
\text { EGYPTIAN } \\
\text { AG } 3905 \\
\text { DK } 3964\end{array}$ & $\begin{array}{l}\text { IV } \\
\text { IV } \\
\text { III } \\
\text { III }\end{array}$ & $\begin{array}{l}62 \\
62 \\
31 \\
31\end{array}$ & $\begin{array}{l}89 \\
89 \\
49 \\
49\end{array}$ & $\begin{array}{r}101 \\
101 \\
65 \\
65\end{array}$ & $\begin{array}{r}128 \\
128 \\
87 \\
87\end{array}$ & $\begin{array}{r}148 \\
148 \\
99 \\
99\end{array}$ & $\begin{array}{l}158 \\
158 \\
113 \\
113\end{array}$ & $\begin{array}{l}166 \\
166 \\
120 \\
120\end{array}$ \\
\hline
\end{tabular}

${ }^{\mathrm{z}} \mathrm{MG}$ refers to maturity group of the genotypes. 


\section{Results}

Environmental data. The daily maximum air temperature, rainfall, and water from irrigation applied from May to October in 2004 and 2005 are shown in Figure 1. Crop water deficit at this test site usually developed from June through September in non-irrigated plots and was detectable in both 2004 and 2005 (Table 2). The soil water potential values among experiments varied between years due to irrigation and rain. Soil water potential for the nonirrigated areas ranged from -5 to $-153 \mathrm{kPa}$ in 2004 and from -5 to $-180 \mathrm{kPa}$ in 2005 (Table 2). Soil temperatures measured at 5.1- and 10 -cm depth in non-irrigated experiments were higher for the entire growing season in 2005 than in 2004 (Table 2). The soil water potential values for the four experiments varied between years due to irrigation and precipitation (Fig. 1 and Table 2). In 2004, the monthly mean water potential in irrigated plots for May through July was 0 to $-5 \mathrm{kPa}$, and for July through August it ranged from -5 to $-10 \mathrm{kPa}$. In the non-irrigated plots, there was a steady decrease in water potential from $-5 \mathrm{kPa}$ in May to $-143 \mathrm{kPa}$ in September. Rain was less during the growing season in 2005 than in 2004, and the water potential in the non-irrigated plots in 2005 declined from -5 to $-10 \mathrm{kPa}$ in May to a maximum of $-180 \mathrm{kPa}$ in August.
Population density of $M$. phaseolina. The counts from the five plates represented a total CFU from $0.005 \mathrm{~g}$ of ground tissue. The total CFU was multiplied by a factor of 200 to obtain $\mathrm{CFU} / \mathrm{g}$. There was a significant $(P<0.05)$ genotype-by-year interaction for CFU and AUDPC for each experiment. Therefore, the data for each year and experiment are presented separately. In 2004, experiment 1 (irrigated and artificially infested) (Fig. 2A), the earliest detection of M. phaseolina was from DK 3964 at the R3 growth stage with $67 \mathrm{CFU} / \mathrm{g}$. A comparison of CFU between genotypes at the R7 stage indicated there were significantly $(P<0.05)$ greater $\mathrm{CFU}$ in the susceptible DK 3964 and Egyptian genotypes with 5,867 and 6,200 , respectively, compared to the moderately resistant genotypes, DT97-4290 and AG 3905 with 933 and 3,867, respectively. Similarly, the AUDPC (Fig. 2A, data in parentheses) was significantly lower $(P<0.05)$ for DT97-4290 (73) and AG 3905 (301) compared to DK $3964(1,907)$ and Egyptian $(700)$. In experiment 2 (irrigated and non-infested) (Fig. 2B), the first CFU was not detected until the R7 growth stage. The susceptible genotypes DK 3964 and Egyptian had significantly $(P<0.05)$ higher CFU of 3,467 and 4,400 at the R7 growth stage, respectively, than the moderately resistant genotypes DT97-4290 and AG 3905 that had CFU of 800 each. The AUDPC was also significantly $(P<0.05)$ lower
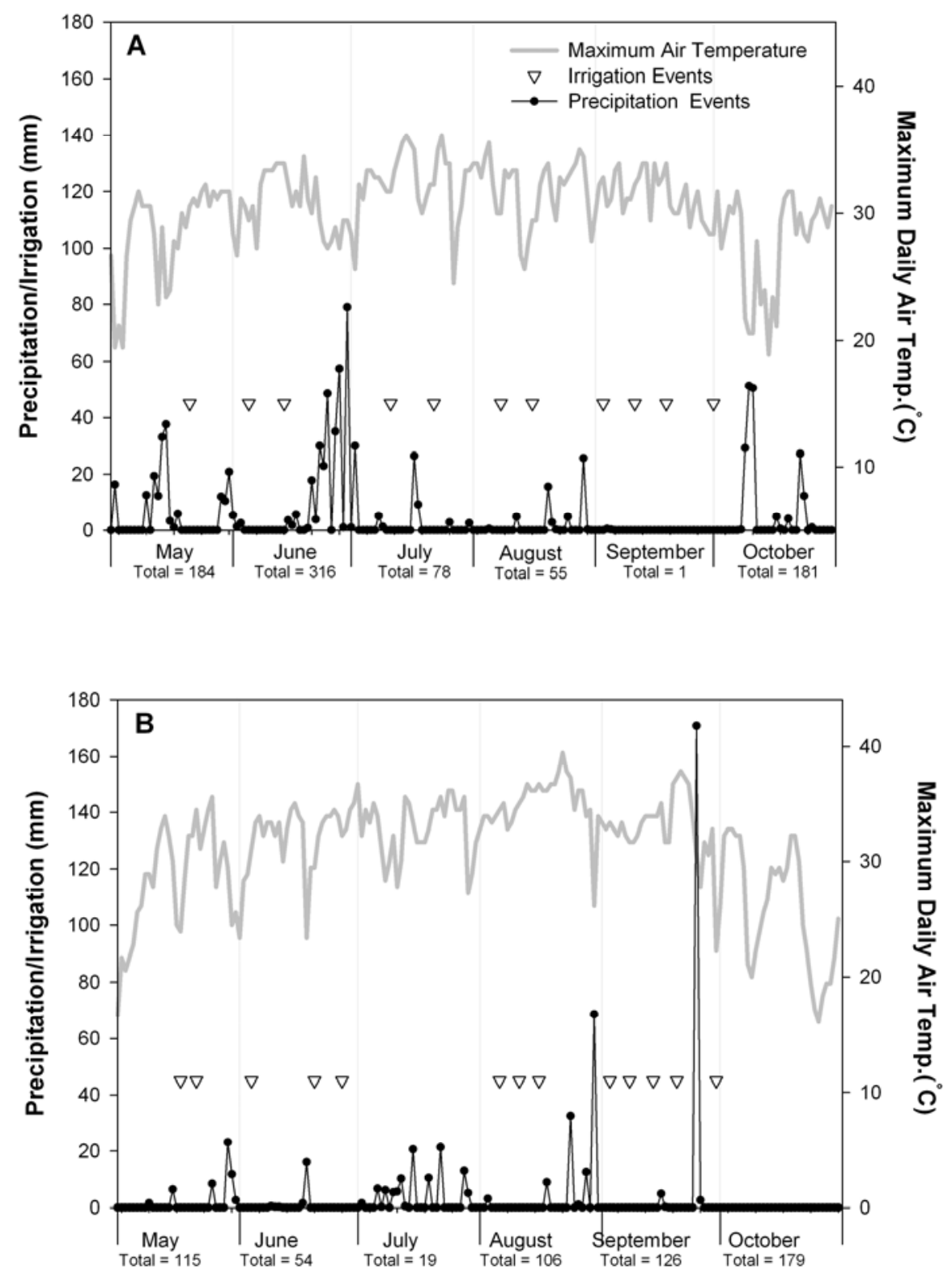

Fig. 1. Relationships between daily maximum air temperature and precipitation in soybean research plots from May to October for 2004 (A) and 2005 (B). The total amount of rainfall for each month is indicated as 'Total' in the figure. 
for DT97-4290 and AG 3905, both at 62, compared to DK 3964 and Egyptian with 1,594 and 507, respectively. In experiment 3 (non-irrigated and artificially infested) (Fig. 2C), the initial CFU for the two susceptible genotypes was detected at the R5 growth stage, and it reached a maximum at growth stage R7 of 13,733 for DK 3964 and 17,067 for Egyptian, respectively. This was significantly $(P<0.05)$ greater than the two moderately resistant genotypes DT97-4290 and AG 3905 that had CFU of 2,533 and 10,000, respectively, at R7. The AUDPC for DT97-4290 and AG 3905 were also significantly $(P<0.05)$ lower (197 and 778, respectively) than those for the DK 3964 and Egyptian (9,657 and 4,097, respectively). In experiment 4 (non-irrigated and non-infested) (Fig 2D), the earliest CFU detection was from Egyptian at the R5 growth stage with $67 \mathrm{CFU} / \mathrm{g}$. DK 3964 reached a maximum of 14,467 CFU while Egyptian reached only 6,600 CFU. The AUDPC for DT97-4290 and AG 3905 were 1,260 and 721, respectively. These values were significantly $(P<0.05)$ lower than the AUDPC for DK 3964 and Egyptian with 6,722 and 1683, respectively.

Table 2. Mean monthly air temperature, precipitation, soil temperatures (at 5.1 and $10 \mathrm{~cm}$ ), and soil water potentials for experiments 1 through 4 in irrigated and non-irrigated environments for 2004 and 2005 in Stoneville, MS

\begin{tabular}{|c|c|c|c|c|c|c|c|c|c|}
\hline \multirow[b]{2}{*}{ Year } & \multirow[b]{2}{*}{ Month $^{\mathrm{x}}$} & \multirow{2}{*}{ 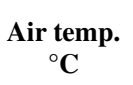 } & \multirow{2}{*}{$\begin{array}{l}\text { Precipitation } \\
\quad(\mathbf{m m})\end{array}$} & \multirow{2}{*}{$\begin{array}{l}\text { Soil temp. }{ }^{\mathrm{y}} \\
5.1 \mathrm{~cm}\left({ }^{\circ} \mathrm{C}\right)\end{array}$} & \multirow{2}{*}{$\begin{array}{l}\text { Soil temp. }{ }^{y} \\
10 \mathrm{~cm}\left({ }^{\circ} \mathrm{C}\right)\end{array}$} & \multicolumn{4}{|c|}{ Soil water potential $(\mathbf{k P a})^{\mathrm{w}}$} \\
\hline & & & & & & Exp. 1 & Exp. 2 & Exp. 3 & Exp. 4 \\
\hline \multirow[t]{6}{*}{2004} & May & 28.46 & 184.15 & 31.11 & 28.26 & -5 & -5 & -5 & -10 \\
\hline & June $^{z}$ & 30.61 & 316.23 & 35.12 & 31.92 & -5 & -5 & -10 & -10 \\
\hline & July $^{z}$ & 32.29 & 78.23 & 38.32 & 34.53 & -5 & -5 & -25 & -40 \\
\hline & August $^{z}$ & 31.86 & 54.61 & 38.23 & 34.34 & -5 & -10 & -15 & -80 \\
\hline & September & 31.43 & 0.76 & 36.09 & 32.61 & -5 & -5 & -120 & -143 \\
\hline & October & 27.65 & 181.10 & 28.12 & 25.95 & -10 & -10 & -142 & -153 \\
\hline \multirow[t]{6}{*}{2005} & May & 28.35 & 53.59 & 34.07 & 30.22 & -5 & -5 & -5 & -10 \\
\hline & June $^{\mathrm{z}}$ & 32.04 & 18.54 & 38.72 & 34.41 & -5 & -5 & -45 & -25 \\
\hline & Julyz & 32.89 & 106.43 & 38.57 & 34.55 & -35 & -25 & -65 & -85 \\
\hline & August $^{2}$ & 35.05 & 126.49 & 40.68 & 36.63 & -40 & -45 & -120 & -145 \\
\hline & September & 32.93 & 178.56 & 36.56 & 33.06 & -45 & -40 & -165 & -180 \\
\hline & October & 25.82 & 0.00 & 30.59 & 27.38 & -45 & -50 & -142 & -153 \\
\hline
\end{tabular}

${ }^{w}$ Negative soil water potential $(\mathrm{kPa})$ and irrigation environments: IRR $=$ irrigated and Non-IRR $=$ non-irrigated. Experiment 1 , IRR-artificially infested; experiment 2, IRR-non-infested; experiment 3, non-IRR artificially infested; experiment 4, non-IRR non-infested.

${ }^{\mathrm{x}}$ May- October refers to periods from planting to harvest.

${ }^{y}$ Data were obtained from the Stoneville weather station website.

${ }^{\mathrm{z}}$ June - August refers to the critical dry months.

\section{A- Irrigated \& artificially infested}

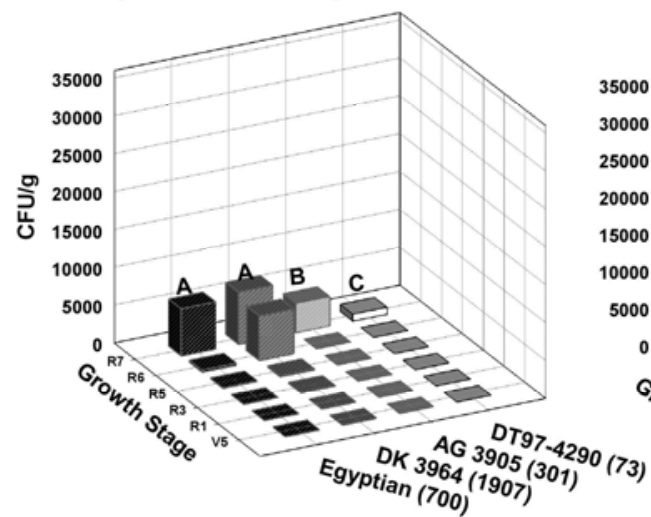

B- Irrigated \& non-infested

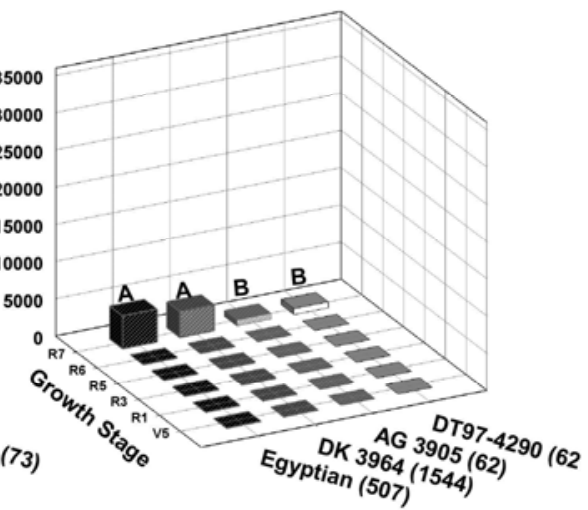

C- Non-irrigated \& artificially infested

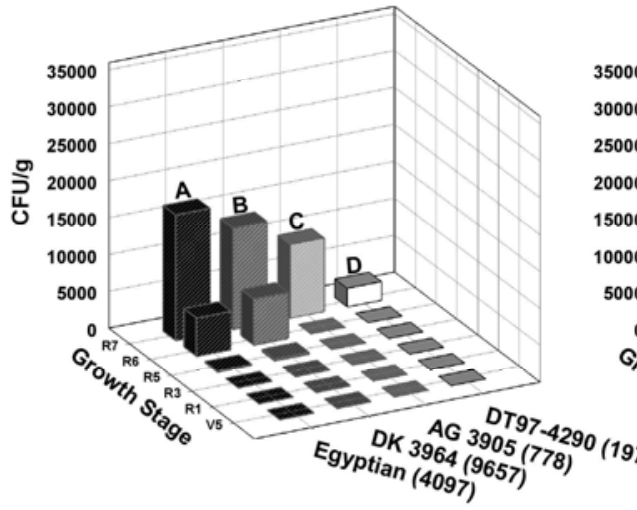

D- Non-irrigated \& non-infested

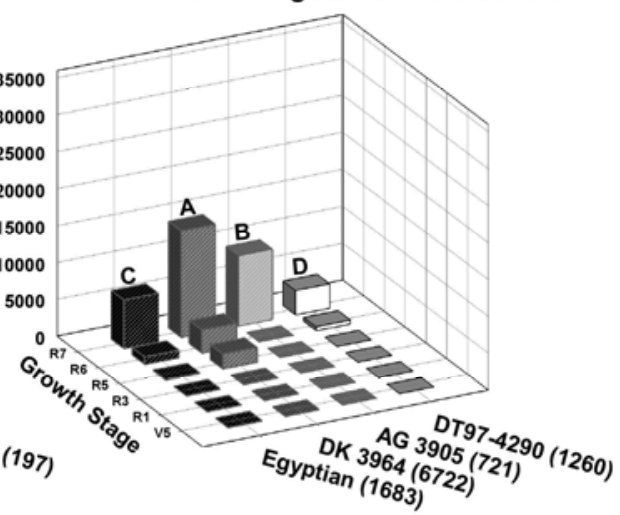

Fig. 2. Progress of colony-forming units (CFU) in lower stem and root tissues for soybean genotypes grown under two irrigation regimes in 2004. X-axis denotes the four soybean genotypes. Z-axis indicates growth stages. A, Experiment 1, irrigated and artificially infested, B, Experiment 2, irrigated and noninfested, C, Experiment 3, not irrigated and artificially infested, and D, Experiment 4, not irrigated and noninfested. Values for the area under the disease progress curve (AUDPC) are given in the parenthesis on the X-axis. Means followed by the same letter for CFU at R7 growth stage are not significantly different from each other $(P<0.05)$. 
In 2005, experiment 1 (Fig. 3A), the earliest detection of $M$. phaseolina occurred at the V5 growth stage on Egyptian with 67 CFU/g. Similar to 2004, DK 3964 and Egyptian also had the highest CFU with 30,600 and 28,067, respectively, at the R7 stage. The moderately resistant genotypes DT97-4290 and AG 3905 had 9,867 and 26,267 CFU/g, respectively. The AUDPC for DT974290 and AG 3905 were 4,521 and 3,961, while for DK 3964 and Egyptian it was 3,854 and 8,791 , respectively. In experiment 2 (Fig. 3B), the earliest detection of M. phaseolina was at the V5 growth stage on the genotype DK 3964, with 67 CFU/g. Significantly $(P<0.05)$ higher CFU were also obtained at R7 from Egyptian and DK 3964, with 35,067 and 27,067, respectively, compared to the moderately resistant genotypes DT97-4290 and AG 3905, which had 8,667 and 7,533 CFU, respectively. There was also a significant difference $(P<0.05)$ in AUDPC between the resistant genotypes DT97-4290 and AG 3905, with 674 and 586, and the susceptible genotypes DK 3964 and Egyptian, with 2,691 and 2,136, respectively. In experiment 3 (Fig. 3C), the earliest detection of M. phaseolina was at the R3 growth stage on DK 3964, with 67 CFU/g. The highest CFU at R7 was from DK 3964 and Egyptian, with 34,600 and 27,467 CFU, respectively, which was significantly $(P<0.05)$ greater than the CFU of their counterpart moderately resistant genotypes DT97-4290 and AG 3905, which had 5,800 and 8,400 CFU, respectively. The AUDPC for DT97-4290 was 649, and that for AG 3905 was 1,121 , which were significantly $(P<$ 0.05) lower than those of DK 3964 (2,691) and Egyptian $(2,136)$. In experiment 4 (Fig. 3D), the earliest detection of M. phaseolina was on three genotypes at R5 with $67 \mathrm{CFU} / \mathrm{g}$ for DT97-4290, DK 3964, and Egyptian. Egyptian and DK 3964, however, had significantly $(P<0.05)$ higher levels of CFU at the R7 growth stage, with 23,867 and 17,533, compared to DT97-4290 and AG 3905, with
CFU of 2,067 and 7,600, respectively. The AUDPC of DT97-4290 and AG 3905 was 368 and 591, respectively, which were also significantly $(P<0.05)$ lower than those of DK $3964(3,776)$ and Egyptian $(1,856)$.

Effects of irrigation and inoculation on soybean yield. There was a significant $(P<0.05)$ genotype-by-year interaction for yield for each experiment, so data for each year and experiment are presented separately (Table 3). In 2004 in experiment 1 (irrigated and artificially infested), the yield of DK 3964 was significantly $(P<$ 0.05 ) lower $(33 \%)$ than its resistant counterpart, AG 3905 (both MG III genotypes; yield difference of $1,317 \mathrm{~kg} / \mathrm{ha}$ ), while the yield of Egyptian was significantly $(P<0.05)$ lower $(18 \%)$ than its resistant counterpart, DT97-4290 (yield difference of $712 \mathrm{~kg} / \mathrm{ha}$; both late MG IV genotypes). In experiment 2 (irrigated and noninfested), the yield of DK 3964 was 10\% lower (yield difference of $462 \mathrm{~kg} / \mathrm{ha}$ ) than AG 3905 and was significant at $P<0.10$, while the yield of Egyptian was $19 \%$ lower (yield difference of $887 \mathrm{~kg} / \mathrm{ha}$ ) and significantly different $(\mathrm{P}<0.05)$ than DT97-4290. In experiment 3 (non-irrigated and artificially infested), the yield of DK 3964 was lower (2\%), but not significantly different from AG 3905 (yield difference of $54 \mathrm{~kg} / \mathrm{ha}$ ). The yield of Egyptian was significantly $(P<0.05)$ lower $(17 \%)$ than that of DT97-4290 $(P<0.05)$ (yield difference of $563 \mathrm{~kg} / \mathrm{ha}$ ). In experiment 4 (non-irrigated and non-infested), however, the yields of the resistant genotypes, AG 3905 and DT97-4290, were less than the yields of their susceptible counterparts DK 3964 and Egyptian, but not significantly different $(P<0.05$ or $P<0.10)$.

In 2005 in experiment 1 (Table 3), the yield loss for the susceptible genotype DK 3964 was $8 \%$ (yield difference of $311 \mathrm{~kg} / \mathrm{ha}$ ), which was significant at $P<0.10$. Similarly, there was a $7 \%$ yield difference $(223 \mathrm{~kg} / \mathrm{ha})$ between DT97-4290 and Egyptian, which
A- Irrigated \& artificially infested

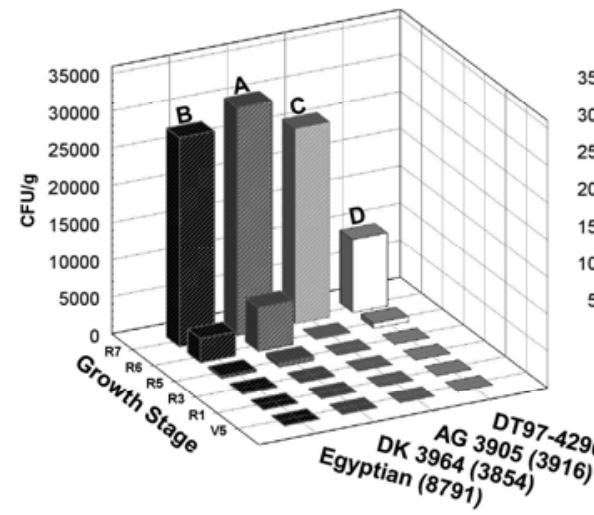

C- Non-irrigated \& artificially infested

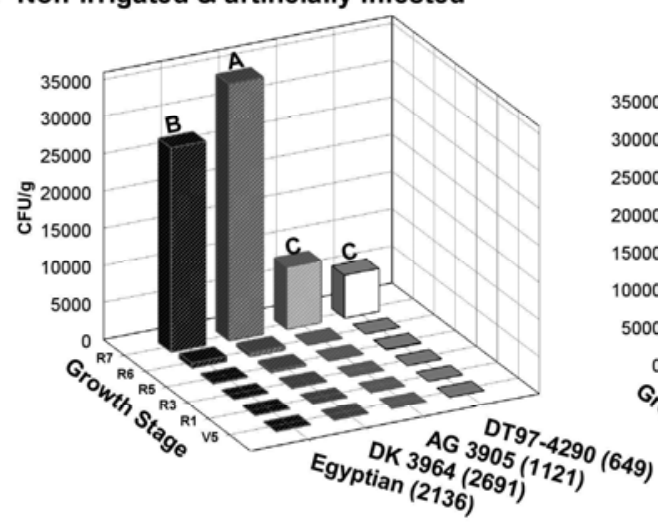

\section{B- Irrigated \& non-infested}

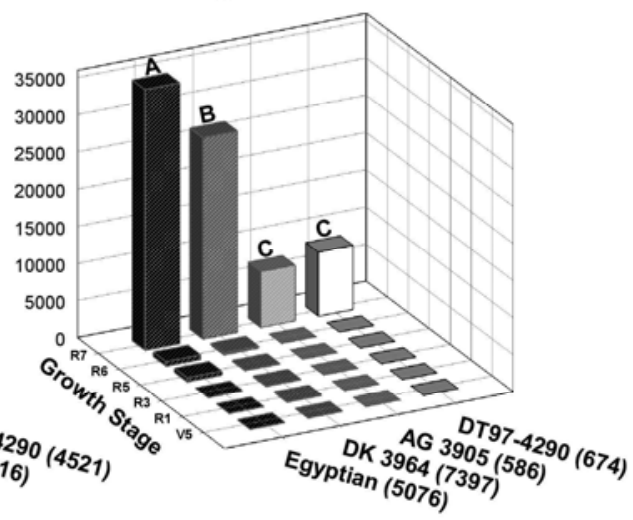

D- Non-irrigated \& non-infested

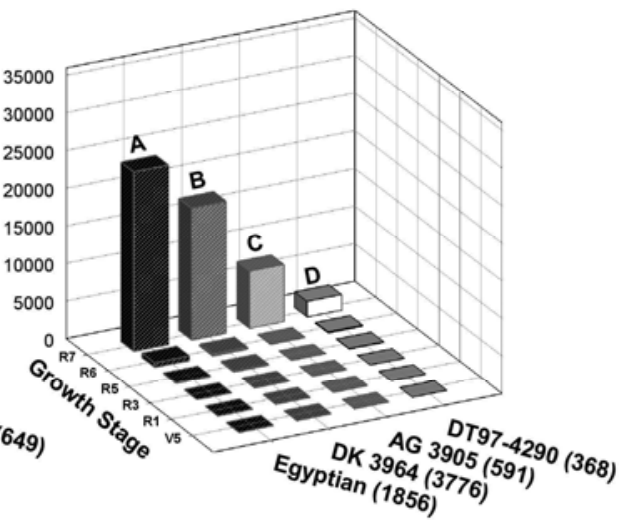

Fig. 3. Progress of colony-forming units (CFU) in lower stem and root tissues for soybean genotypes grown under two irrigation regimes in 2005 . X-axis denotes the four soybean genotypes. Z-axis indicates growth stages. A, Experiment 1, irrigated and artificially infested, B, Experiment 2, irrigated and noninfested, C, Experiment 3, not irrigated and artificially infested, and D, Experiment 4, not irrigated and noninfested. Values for the area under the disease progress curve (AUDPC) are given in parentheses on the X-axis. Means followed by the same letter for CFU at R7 growth stage are not significantly different from each other $(P<0.05)$. 
was also significant at $P<0.10$. In experiment 2 , the yield of DK 3964 was $6 \%$ lower than AG 3905 (yield difference of $209 \mathrm{~kg} / \mathrm{ha}$ ) and significantly different at $P<0.10$, while Egyptian yielded $16 \%$ less than DT97-4290 (yield difference of $565 \mathrm{~kg} / \mathrm{ha}$ ), which was significant $(P<0.05)$. In experiment 3 , the yield of DK 3964 was $7 \%$ lower than AG 3905 (yield difference of $208 \mathrm{~kg} / \mathrm{ha}$ ) and significant at $P<0.10$, while the yield of Egyptian was $13 \%$ lower than that of DT97-4290 (yield difference of $302 \mathrm{~kg} / \mathrm{ha}$ ) and significant $(P<0.05)$. In experiment 4 , the yields of the susceptible genotypes DK 3964 and Egyptian exceeded that of their resistant counterparts Ag 3905 and DT97-4290, with yields of -217 and $-90 \mathrm{~kg} / \mathrm{ha}$ ), respectively, but these differences were not significant $(P<0.05$ or $P<0.10)$.

Over both years, under all irrigated comparisons, the resistant genotype yielded more than the susceptible genotypes in all of the eight paired comparisons, with four of the eight comparisons significant at $P<0.05$ and the other four significant at $P<0.10$. Under non-irrigation, however, resistant lines yielded significantly $(P$ $<0.05)$ more than the susceptible in only two of the eight comparisons. In two of the eight comparisons, there was a significant difference at $P<0.10$, while in four of the comparisons, there was no significant difference at either $P<0.05$ or $P<0.10$ (Table 3).

The yield advantage of genotypes under irrigation compared to those under non-irrigation, expressed as percentage of yield of irrigation, ranged between 11 and 19\% in artificially infested plots

Table 3. Yield difference $(\mathrm{kg} / \mathrm{ha})$ between moderately resistant and susceptible genotypes and percent yield difference between two cultivars within each maturity group in irrigated and not-irrigated environments in plots artificially infested and non-infested with Macrophomina phaseolina in 2004 and 2005 in Stoneville, MS ${ }^{z}$

\begin{tabular}{|c|c|c|c|c|}
\hline \multirow[b]{2}{*}{ Matching genotypes } & \multicolumn{2}{|c|}{2004} & \multicolumn{2}{|c|}{2005} \\
\hline & $\begin{array}{l}\text { Yield } \\
\text { diff. }\end{array}$ & $\begin{array}{l}\% \text { Yield } \\
\text { diff. }\end{array}$ & $\begin{array}{l}\text { Yield } \\
\text { diff. }\end{array}$ & $\begin{array}{l}\% \text { Yield } \\
\text { diff. }\end{array}$ \\
\hline \multicolumn{5}{|c|}{ Experiment 1 , Irrigated and artificially infested } \\
\hline DT97-4290 vs. Egyptian & 712 & $18 * *$ & 223 & $7 *$ \\
\hline AG 3905 vs. DK 3964 & 1,317 & $33 * *$ & 311 & $8^{*}$ \\
\hline \multicolumn{5}{|c|}{ Experiment 2, Irrigated and non-infested } \\
\hline DT97-4290 vs. Egyptian & 887 & $19 * *$ & 565 & $16^{* *}$ \\
\hline AG 3905 vs. DK 3964 & 462 & $10^{*}$ & 209 & $6^{*}$ \\
\hline \multicolumn{5}{|c|}{ Experiment 3 , Non-irrigated and artificially infested } \\
\hline DT97-4290 vs. Egyptian & 563 & $17 * *$ & 302 & $13^{* *}$ \\
\hline AG 3905 vs. DK 3964 & 54 & $2 \mathrm{~ns}$ & 208 & $7 *$ \\
\hline \multicolumn{5}{|c|}{ Experiment 4 , Non-irrigated and non-infested } \\
\hline DT97-4290 vs. Egyptian & -30 & $-3 \mathrm{~ns}$ & -90 & $-5 \mathrm{~ns}$ \\
\hline AG 3905 vs. DK 3964 & -94 & $-1 \mathrm{~ns}$ & -217 & $-7 *$ \\
\hline
\end{tabular}

$\mathrm{z} * *$ Yield differences that were significant at $P<0.05$; *Yield differences that were significant at $P<0.10$, and ns $=$ not significant at any two probability levels. DT97-4290 and Egyptian are late MG IVs and AG 3905 and DK 3964 are MG III genotypes. and 26 to $49 \%$ in non-infested plots (Table 4) in 2004. In contrast, when similar comparisons were made for 2005 , the yield advantage under irrigation ranged from 23 to $33 \%$ in artificially infested plots and from -2 to $42 \%$ in non-infested plots (Table 4 ).

When percent yield difference between moderately resistant and susceptible genotypes in irrigated environments over 2 years were regressed against CFU at R7 growth stage, the CFU explained $42 \%$ of the variation and was significant $(P<0.05)$. On the other hand, when similar data from the non-irrigated experiments were pooled over the 2 years and infestation levels, and regressed against CFU, only $9 \%$ of the variation was explained by CFU. When AUDPC was regressed against the yield differences for the resistant and susceptible genotypes, AUDPC explained $36 \%$ of the variation in the irrigated and only $2 \%$ of the variation in the non-irrigated environments.

\section{Discussion}

Disease pressure was high during both years, indicating that the environmental conditions and inoculum levels were favorable for infection. M. phaseolina was isolated from field grown plants at the V5 stage. There was little increase in colonization throughout the vegetative and the reproductive stages until R5 or R6, and disease peaked at the R7 growth stage when soybean plants were senescing (28). At this stage, accumulation of dry matter ceases (24) followed by increased level of $M$. phaseolina infection. Growth stage R8 was not sampled since saprophytic colonization by $M$. phaseolina may negate any observable genetic differences in infection levels.

The frequency with which $M$. phaseolina CFUs were recovered from lower stems and roots on the four genotypes was influenced more by year effects than by the experiment type. Disease progress, for example, was reduced in 2004 (Fig. 2), and the higher CFU level in 2005 (Fig. 3) may also have been accentuated due to higher air and soil temperatures and lower soil water potentials (Table 2). Low soil water potential was associated with high CFU recovery, but was also associated with low yield. During 2004, the ambient and soil temperatures were cooler than in 2005, and this may have decreased microsclerotia germination or slowed the growth of the pathogen within the plants and subsequently reduced host tissue colonization.

In 2005, the yield differences between resistant and susceptible soybean genotypes were much smaller than the difference in yield detected for the same genotypes in 2004 and ranged from 6 to $16 \%$. These yield differences can be attributed to higher CFU levels favored by the conditions of higher air and soil temperatures combined with lower total precipitation. These results suggest that yield loss due to charcoal rot may be high under conditions where soybean yield potential is high. This is contrary to previous reports where yield loss estimation was based on anecdotal evidence obtained primarily from non-irrigated environments using field surveys, cultivar trials, and questionnaires by field workers and exten-

Table 4. Yield in $\mathrm{kg} / \mathrm{ha}$ for genotypes in irrigated, non-irrigated, infested, and non-infested environments and percent yield loss expressed as a percentage of yield under irrigation in plots artificially infested and non-infested with Macrophomina phaseolina in 2004 and 2005 in Stoneville, MS

\begin{tabular}{|c|c|c|c|c|c|c|}
\hline Genotype & $\begin{array}{c}\text { Irrigated } \\
\text { Experiment 1 } \\
\text { Artificially infested }\end{array}$ & $\begin{array}{c}\text { Not irrigated } \\
\text { Experiment } 3 \\
\text { Artificially infested }\end{array}$ & $\%$ Yield loss & $\begin{array}{c}\text { Irrigated } \\
\text { Experiment } 2 \\
\text { Non-infested }\end{array}$ & $\begin{array}{l}\text { Not irrigated } \\
\text { Experiment } 4 \\
\text { Non-infested }\end{array}$ & $\%$ Yield loss \\
\hline \multicolumn{7}{|l|}{2004} \\
\hline DT $97-4290$ & $4,004 \mathrm{~A}^{\mathrm{z}}$ & $3,234 \mathrm{~A}$ & 19 & $4,712 \mathrm{~A}$ & $2,404 \mathrm{C}$ & 49 \\
\hline EGYPTIAN & $3,292 \mathrm{~B}$ & $2,671 \mathrm{~B}$ & 19 & $3,825 \mathrm{~B}$ & $2,434 \mathrm{BC}$ & 36 \\
\hline AG 3905 & $4,040 \mathrm{~A}$ & $3,604 \mathrm{~A}$ & 11 & $4,756 \mathrm{~A}$ & $3,104 \mathrm{AB}$ & 35 \\
\hline DK 3964 & $2,723 \mathrm{~B}$ & $3,550 \mathrm{~A}$ & -30 & $4,294 \mathrm{~B}$ & 3,198 A & 26 \\
\hline \multicolumn{7}{|l|}{2005} \\
\hline DT $97-4290$ & $3,184 \mathrm{~B}$ & $2,286 \mathrm{BC}$ & 28 & $3,460 \mathrm{~A}$ & $2,022 \mathrm{~B}$ & 42 \\
\hline EGYPTIAN & $2,961 \mathrm{BC}$ & $1,984 \mathrm{C}$ & 33 & $2,895 \mathrm{AB}$ & $2,112 \mathrm{~B}$ & 27 \\
\hline AG 3905 & $4,029 \mathrm{~A}$ & $3,089 \mathrm{~A}$ & 23 & $3,468 \mathrm{~A}$ & $3,091 \mathrm{~A}$ & 11 \\
\hline DK 3964 & $3,718 \mathrm{~A}$ & $2,881 \mathrm{AB}$ & 23 & $3,259 \mathrm{~A}$ & $3,308 \mathrm{~A}$ & -2 \\
\hline
\end{tabular}

\footnotetext{
${ }^{\mathrm{z}}$ Means followed by the same letter are not significantly different from each other $(P<0.05)$. DT97-4290 and Egyptian are late MG IVs, and AG 3905 and
} DK 3964 are MG III genotypes. 
sion agents $(16,17,22,25,30-34)$ and may not reflect the actual yield loss due to charcoal rot itself.

The extent of yield differences was also influenced by the combined effects of non-irrigation and charcoal rot severity. Total yield reduction for each genotype was greatest when CFU levels in root and stem tissues were high under non-irrigated conditions. In the non-irrigated environments, however, not only were yield differences between resistant and susceptible genotypes narrowed, but yields of susceptible genotypes exceeded those of their resistant counterparts. In experiment 4 , for example, the susceptible genotypes in four of the paired comparisons yielded greater than their resistant counterparts. This may be directly related to the low soil water potential measured in August and September in Stoneville, MS, where it was -80 and $-143 \mathrm{kPa}$ in 2004 and -145 and -180 $\mathrm{kPa}$ in 2005, respectively (Table 2).

The increase in genotype yield in the irrigated environments compared to the yield of genotypes in non-irrigated environments was likely due to adequate availability of moisture for plant growth. Irrigation may have removed the confounding effect of drought and allowed a yield increase to occur. The amount of yield loss attributed to charcoal rot, however, cannot be determined when there is drought stress associated with non-irrigated treatments. This is in agreement with Bowen and Schapaugh (2), who reported no association between charcoal rot severity and yield in a non-irrigated environment.

Comparisons of yield among soybean genotypes in a non-irrigated environment may result in underestimating the losses from this disease. Furthermore, the inability to eradicate the fungus in field experiments using methyl bromide (21) and other control measures, and the unavailability of soybean genotypes with a high level of resistance to charcoal rot are additional factors that complicate the understanding of the relationship of yield and charcoal rot when tested in non-irrigated environments.

In order to estimate yield loss due to drought or the combined effects of drought and charcoal rot, the data in Tables 3 and 4 are highly informative. Yield loss inferences may be drawn to separate the disease loss component from the drought component. For example, when considering the yield losses in experiment 1 (artificially infested and irrigated) and experiment 2 (non-infested and irrigated) and the data pooled over 2004 and 2005, the effects of charcoal rot alone (after the drought effect was removed) resulted in a yield loss of $15 \%$. However, when data from experiment 3 (artificially infested and non-irrigated) and experiment 4 (non-infested and non-irrigated) were pooled over 2004 and 2005, the yield loss was $22 \%$, suggesting that from the combined effects of drought and charcoal rot, drought contributed an additional 7\% yield loss. This inferred comparison may suggest that the combined effects of charcoal rot and drought may exceed the loss due to either of these stresses alone. Soybeans that are non-irrigated are often prone to drought. Drought is not only an abiotic factor that can independently reduce soybean yield but is a predisposing factor that may promote $M$. phaseolina infection. Additional research may be needed to determine whether the effects of drought and infection by M. phaseolina are additive, synergistic, or independent (35).

Most management recommendations for reducing charcoal rot severity focus on reducing crop stress and maintaining plant vigor by irrigation (28). While yield is improved greatly in irrigated compared to non-irrigated environments, the high-yielding irrigated environment did not prevent charcoal rot from impacting yield. This suggests that charcoal rot can be an important disease under such conditions. Our results indicate that yield loss assessment in non-irrigated and $M$. phaseolina infested environments may result in false yield loss estimates for charcoal rot. By comparing the performance of genotypes in an irrigated environment, however, we were able to differentiate the infection levels and yield differences between moderately resistant and susceptible genotypes in all the comparisons. Moderate levels of resistance to $M$. phaseolina conferred a yield advantage in soil with high population of $M$. phaseolina and under conditions that favored both disease and host growth.
Our results showed that infection by $M$. phaseolina occurred under both irrigated and non-irrigated environments, but this is the first report that yield loss due to M. phaseolina can be measured accurately in irrigated environments. Evaluation and selection of soybean genotypes for resistance to M. phaseolina have been performed in non-irrigated environments $(15,27)$. Based on this study, however, screening soybean genotypes under irrigation environment may have utility in breeding programs where there is a need for evaluating soybean genotypes for both disease resistance and yield.

\section{Acknowledgments}

We thank Debbie Boykin, USDA statistician, for her assistance with data analysis. We thank the Mississippi Soybean Promotion Board, the North Central Soybean Research Program, and the USDA (project 6401-21220-002-00D) for providing funding to support this research. In addition, we thank Avis Clark, Matilda Harris, Gary Shelton, and Will Marlow for their assistance in laboratory and field tests, and Jason Deffenbaugh and Jamie Jordan for their assistance with graphics.

\section{Literature Cited}

1. Birrenkott, G. L., Mengistu, A., and Grau, C. R. 1984. First report of charcoal rot caused by Macrophomina phaseolina on soybeans in Wisconsin. Plant Dis. 68:628.

2. Bowen, C. R., and Schapaugh, W. T. 1989. Relationships among charcoal rot infection, yield, and stability estimates in soybean blends. Crop Sci. 29:42-46

3. Chen, S. Y., Porter, P. M., Orf, J. H., Reese, C. D., Stienstra, W. C., Young, N. D., Walgenbach, D. D., Schaus, E J., Arlt, T. J., and Breitenbach, E. R. 2001. Soybean cyst nematode population development and associated soybean yields of resistant and susceptible cultivars in Minnesota. Plant Dis. 85:760-766.

4. Danielson, G. A., Nelson, B. D., and Helms, T. C. 2004. Effect of Sclerotinia stem rot on yield of soybean inoculated at different growth stages. Plant Dis. 88:297-300.

5. Dhingra, O. D., and Sinclair, J. B. 1974. Effect of soil moisture and carbon:nitrogen ratio on survival of Macrophomina phaseolina in soybean stems in soil. Plant Dis. Rep. 58:1034-1037.

6. ElAraby, M. E., Kurle, J. E., and Stetina, S. R. 2003. First report of charcoal rot (Macrophomina phaseolina) on soybean in Minnesota. Plant Dis. 87:202.

7. Fehr, W. R., Caviness,C. E., Burmood, D. T., and Pennington, J. S. 1971 Stage of development descriptions for soybeans, Glycine max (L.) Merrill. Crop Sci. 11:929-931.

8. Gary, F. A., Mihail, J. D., Lavigne, R. J., and Porter, P. M. 1991. Incidence of charcoal rot of sorghum and soil populations of Macrophomina phaseolina associated with sorghum and native vegetation in Somalia. Mycopathologia 114:145-151.

9. Heatherly, L. G. 1999. Early soybean production system (ESPS). Pages 103-118 in: Soybean Production in the Midsouth. L. G. Heatherly and H. F. Hodges, eds. CRC Press, Boca Raton, FL.

10. Kendig, S. R., Rupe, J. C., and Scott, H. D. 2000. Effect of irrigation and soil water stress on densities of Macrophomina phaseolina in soil and roots of two soybean cultivars. Plant Dis. 84:895-900.

11. Manici, L. M., Caputo, F. A., and Cerato, C. 1995. Temperature responses of isolates of Macrophomina phaseolina from different climatic regions of sunflower production in Italy. Plant Dis. 79:934-938.

12. Mengistu, A., Castlebury, L., Smith, R., Ray, J., and Bellaloui, N. 2009. Seasonal progress of Phomopsis longicolla infection on soybean plant parts and its relationship to seed quality. Plant Dis. 93:1009-1018.

13. Mengistu, A., and Grau, C. R. 1987. Seasonal progress of brown stem rot and its impact on soybean productivity. Phytopathology 77:1521-1529.

14. Mengistu, A., Krishna, N., Reddy, R., Zablotowicz, M., and Wrather, A. J. 2008. Propagule densities of Macrophomina phaseolina in soybean tissue and soil as affected by tillage, cover crop, and herbicides. Plant Health Progress. doi:10.1094/PHP-2009-0130-01RS.

15. Mengistu, A., Ray, J. D., Smith, J. R., and Paris, R. L. 2007. Charcoal rot disease assessments of soybean genotypes using a colony forming unit index. Crop Sci. 47:2453-2461.

16. Mulrooney, R. P. 1988. Soybean disease loss estimate for southern United States in 1985 and 1986. Plant Dis. 72:364-365.

17. Mulrooney, R. P. 1988. Soybean disease loss estimate for southern United States in 1987. Plant Dis. 72:915.

18. Norton, D. C. 1953. Linear growth of Sclerotium bataticola through soil. Phytopathology 43:633-636.

19. Oval, M., Jr., and Schmidt, M. E. 1987. Registration of 'Egyptian' soybean. Crop Sci. 27: 817-818.

20. Paris, R. L., Mengistu, A., Tyler, J. M., and Smith, J. R. 2006. Registration of soybean Germplasm Line DT97-4290 with moderate resistance to charcoal rot. Crop Sci. 46:2324-2325.

21. Pearson, C. A. S., Schwenk, F. W., Crowe, F. J., and Kelly, K. 1984. Coloni- 
zation of soybean roots by Macrophomina phaseolina. Plant Dis. 68:10861088.

22. Pratt, W. P., and Wrather, J. A. 1998. Soybean disease loss estimates for the southern United States, 1994 to 1996. Plant Dis. 82:114-116.

23. Rabedeaux, R F., Gaska, J. M., Kurtzweil, N. C., and Grau, C. R. 2005. Seasonal progression and agronomic impact of Tobacco streak virus on soybean in Wisconsin. Plant Dis. 89:391-396.

24. Ritchie, S. W., Hanway, J. J., Thompson, H. E., and Benson, G. O. 1989. How a soybean plant develops. Spec. Rep. No. 53. Iowa State Univ. Sci. Technol. Coop. Ext. Serv., Ames, IA.

25. Sciumbato, G. L. 1993. Soybean disease loss estimate for the southern United States during 1988-1991. Plant Dis. 77:954-956.

26. Short, G. E., Wyllie, T. D., and Bristow, P. R. 1980. Survival of Macrophomina phaseolina in soil and in residue of soybean. Phytopathology 70:13-17.

27. Smith, G. S., and Carvil, O. N. 1997. Field screening of commercial and experimental soybean cultivars for their reaction to Macrophomina phaseolina. Plant Dis. 81:363-368.

28. Smith, G. S., and Wyllie, T. D. 1999. Charcoal rot. Pages 29-31 in: Compendium of Soybean Diseases. 4th ed. G. L. Hartman, J. B. Sinclair, and J. C. Rupe, eds. American Phytopathological Society, St. Paul, MN.

29. United States Department of Agriculture. 1995. Agricultural Chemical Usage: 1994Vegetable Summaries. National Agricultural Statistics Service,
Economic Research Service, Washington, DC. No. Ag Ch 1 (95).

30. Whitney, G. 1978. Southern states soybean disease loss estimates-1977. Plant Dis. Rep. 62:1078-1079.

31. Wrather, J. A., Anderson, T. R., Arsyad, D. M., Gai, J., Ploper, L. D., PortaPuglia, A., Porta-Puglia, H. H., and Ram, R. 1997. Soybean disease loss estimates for the top 10 soybean producing countries in 1994. Plant Dis. 81:107-110.

32. Wrather, J. A., Chambers, A. Y., Fox, J. A., Moore, W. F., and Sciumbato, G. L. 1995. Soybean disease loss estimates for the southern United States, 1974 to 1994 . Plant Dis. 79:1076-1079.

33. Wrather, J. A., and Koenning, S. R. 2006. Estimates of disease effects on soybean yields in the United States 2003-2005. J. Nematol. 38:173-180.

34. Wrather, J. A., and Sciumbato, G. L. 1995. Soybean disease loss estimates for the southern United States during 1992-1993. Plant Dis. 79:84-85.

35. Wrather, J. A., Shannon, J. G., Carter, T. E., Bond, J. P., Rupe, J. C., and Almeida, A. M. R. 2008. Reaction of drought-tolerant soybean genotypes to Macrophomina phaseolina. Plant Health Progress doi:10.1094/PHP-20080618-01-RS.

36. Wyllie, T. D. 1988. Charcoal rot of soybean: Current status. Pages 106-113 in: Soybean Diseases of the North Central Region. T. D. Wyllie and D. H. Scott, ed. American Phytopathological Society, St. Paul, MN.

37. Yang, X. B., and Navi, S. S. 2005. First report of charcoal rot epidemics caused by Macrophomina phaseolina in soybean in Iowa. Plant Dis. 89:526. 